\title{
マイクロ波加熱を用いたセラミックスコンパクトプロセス技術
}

\author{
白井 孝 ·安岡正喜 · 堀田裕司 · 渡利広司 \\ 産業技術総合研究所，463-8560 名古屋市守山区下志段味穴ヶ洞 2266-98
}

\section{Development of Compact Process using Microwave Heating}

\author{
Takashi SHIRAI, Masaki YASUOKA, Yuji HOTTA and Koji WATARI
}

National Institute of Advanced Industrial Science and Technology (AIST), 2266-98, Anagahora, Shimo-shidami, Moriyama-ku, Nagoya-shi 463-8560

\begin{abstract}
Conventionally the manufacturing of ceramic parts consists of various processes such as pulverization of raw materials, dispersion, mixing, drying, shape forming, removal of organic binder, sintering and machining. We proposed new manufacturing processes using microwave technique, a technique named "compact process," for the significant enhancement of manufacturing speed and ultimate improvement of productivity of ceramics fabrication, in which the complicated operations are reduced to simplified processes. In this report, the effects on the characteristics of sintered body and decreasing of energy consumption by compact process will be discussed.
\end{abstract} [Received October 18, 2006; Accepted November 16, 2006]

Key-words : Compact process, Microwave heating, Shaping, Binder less, Collapse type mold, Slip casting, Energy consumption

\section{1. 緒 論}

人類は地球温暖化やエネルギー資源の枯渴といった大きな課 題を抱えている．日本においてはエネルギー消費によって生じ る温室効果ガスの約 4 割が，産業部門によって排出されてい $る^{1)}$ 。とりわけセラミックス産業は，部材製造の際，高温でか つ長時間の焼成が必要とされるため，単位製品当たりの消費工 ネルギーが大きく，また製造工程中においては $\mathrm{CO}_{2}$ 等の温室 効果ガスを大量に排出するなど，環境に対する影響は大きい. 一方，近年のセラミックス産業の動向は，ナノテクノロジーや エレクトロニクス，通信分野の急速な発展に伴い，高機能化， 新規機能性付与を目指した高付加価值製品の開発に向かってお り，次世代セラミックスを見据えた製造プロセスの抜本的見直 しが必要である。これら社会的要請を踏まえ，経済性，低環境 負荷性を加味したうえで，工程に要する時間の短縮化，使用す る資源の減量化，投入エネルギーの低減化，工程の最小化を導 く新たな高効率製造プロセス技術の開発が強く求められてい る.

一般にセラミックスは，原料の粉砕，分散・混合，乾燥，成 形，脱脂，焼結，加工といった多くの工程を経て製造される が，従来のプロセスは低環境負荷性を十分に考慮しているとは 言えない，通常の製造プロセスは，(1)工程時間が非常に長い， (2)コストが高い，(3)投入エネルギーが非効率である等の問題点 があるが，著者らは各工程を単純化，短縮化し，(1)量産性の向 上，(2)経済性（特に時間の短縮），(3)環境への適合等を考慮し て, セラミックス部材の生産性の向上を目的とした, コンパク トプロセス技術の開発を目指し研究に取り組んでいる.

今回著者らは，内部加熱や選択的加熱など様々な特徵を持 ち, 効率的なエネルギー投入が可能で，かつ省エネルギー効果 も期待できるマイクロ波技術に着目し，マイクロ波加熱の特徴 （選択的・均一的・内部・急速加熱）を活用したセラミックス 製造における成形・乾燥・焼成の各工程を統合化するコンパク トプロセスを開発した ${ }^{2)}$ 。本稿では，本開発プロセスを紹介 し，本手法により作製した試料と，通常工程により作製した試 料との比較, 検討し, 開発したコンパクトプロセス手法におけ
る工程時間の短縮効果や，省エネルギー化に対する優位性につ いて議論する.

\section{2. コンパクトプロセス}

\section{1 鋳込み成形工程における統合化}

セラミックスの成形法は，その手法の違いにより乾式成形， 塑性成形，押出し成形，鋳込み成形，射出成形，シート成形な ぞに分かれる. 中でも鋳込久成形法は，複雑形状物や衛生陶器 などの大型形状物の成形などに用いられるなど，セラミックス 成形法の中でも一般的な手法である ${ }^{3)}$ 。鋳込み成形には低濃度 のスラリーを，セッコウに代表される吸水性の多孔質鋳型に流 入し，型壁に着肉層を形成させた後，排泥する排泥鋳込久成形 と，濃厚なスラリーを型に流し込みそのまま固化させる固形鋳 込久法がある ${ }^{3)}$. どちらの手法も，脱型後乾燥し，成形体を焼 成炉内にて脱脂, 焼成工程を行い, 後加工を経て製品となる. 非常に汎用性の高い成形手法と言えるが，成形体の乾燥に長い 時間を要する。また複雑な形状を有する成形体を作製する場 合，有機バインダーの添加が不可欠となるが，加熱によりバイ ンダーを除去する脱脂工程は数十時間にも及ぶため，投入工ネ ルギー削減及び生産性向上の観点から，工程の見直しが必要で ある。また脱型時における成形体への損傷や，乾燥，脱脂工程 における欠陷の生成などが問題となる。

今回著者らが開発した新規開発プロセスは，図１に示すよう に，鋳込久成形工程に打的“鋳込久”, “脱型”, “乾燥”, “脱 脂”，“焼成”の各工程を 1 工程に統合化するものである．すな わちスラリーを鋳込久型に流して成形し，脱型することなく， 乾燥から焼成までの一連の加熱工程を，マイクロ波加熱炉内に て行うことで，工程の単略化，工程時間の短縮，投入エネル ギーの削減を達成する低環境負荷型製造プロセスである.

\section{2 新規開発型 一崩壊式成形型一}

今回の開発プロセスは鋳込み後焼成までの加熱工程を，マイ クロ波加熱师内にて行う. そのため通常用いられるセッコウ等 の多孔質吸水型では，焼成時の有害ガス発生や，焼成時の試料 収縮に伴う試料の拘束等, 多々問題があり使用が難しい。よっ 


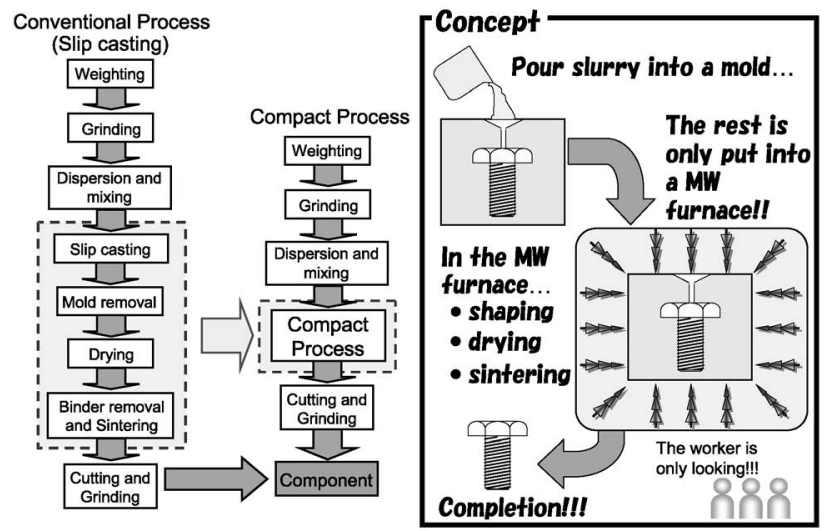

Fig. 1. Concept of simplified manufacturing process using microwave technique.

て今回，崩壊式成形型を新しく開発し，実験に使用した，崩壊 式成形型の特徵は, 鋳込み, 乾燥時には成形型として, 焼成時 には断熱材及びマイクロ波吸収のサセプターとして作用し，ま た焼成後は崩壊するため, 製品の取出しが容易となる等, 複数 の機能を持ち合わせている. 成形, 乾燥, 焼成を同一工程で行 うため脱型工程を省くことができ，バインダーを使う必要がな い. そのため脱脂工程が不要となり, 工程時間の大幅な短縮化 も可能となる. また一般的に鋳込み成形に用いられるセッコウ 型は，着肉時にセッコウ成分である硫酸カルシウムが溶解して 成形体内に混入してしまう難点があるが，今回使用した開発型 は不純物の混入が非常に少ないという特徵がある。

\section{3. 実験方法}

\section{1 崩壊式成形型の作製条件}

平均粒径 $5 \mu \mathrm{m}$ 程度のアルミナ粒子（A-12, 住友化学) と, そのアルミナ粒子に対して 6 mass \% となる割合で食用ゼラチン (セライス, マルハ) を溶かした水溶液を混合して, アルミナの スラリーを作製した。これをシリコンゴム型に流し込み，冷凍 庫で冷し固めることによって，直径 $20 \mathrm{~mm}$ ，高さ $10 \mathrm{~mm}$ の成形 体が得られる崩壞式成形型を作製した。作製した型の相対密 度，開気孔及び閉気孔率はアルキメデス法により測定した。 た型の表面粗さは共焦点型レーザー測定器 (LT-9010M, キーエ ンス）を備えた 3 次元形状測定システム（EMS2002AD-3D，コ ムス）により測定し, 型表面は走査型電子顕微鏡 (SEM, JSM$5600 \mathrm{~N}$ ，日本電子）にて観察した

\section{2 コンパクトプロセス条件}

原料粉末には $\mathrm{ZnO}$ 粉末 (JIS 1 種, ハクスイテック) 及び $\alpha$ $\mathrm{Al}_{2} \mathrm{O}_{3}$ 粉末 $(\mathrm{AKP}-3000$, 住友化学) を用いた。 スラリー濃度が $40 \mathrm{vol} \%$ となるように, 分散剤（PAA）を0.32 mass\%添加し蒸 留水と混合した後, $12 \mathrm{~h}$ ボールミルを行い, スラリーを作製し た。得られたスラリーを今回新規に開発した崩壊式成形型に流 し，マイクロ波炉（MW-master，2.45 Ghz，美濃割業）内にて 成形 · 乾燥 $\left(80^{\circ} \mathrm{C}, 15 \mathrm{~min}, 2 \mathrm{~K} / \mathrm{min}\right)$, 焼成 $\left(\mathrm{ZnO}: 900^{\circ} \mathrm{C}, 10\right.$ $\left.\min , \alpha-\mathrm{Al}_{2} \mathrm{O}_{3}: 1350^{\circ} \mathrm{C}, 30 \mathrm{~min}, 20 \mathrm{~K} / \mathrm{min}\right)$ を同一工程で行った.

比較試料のため, 通常鋳込久工程で用いられることが多い セッコウ型を用い，通常の鋳込み工程により試料を作製した。 スラリーをセッコウ型 $(\phi 20 \mathrm{~mm} \times 10 \mathrm{~mm})$ に鋳込み，成形体 の厚みが約 $5 \mathrm{~mm}$ となるよう時間調整後, 排泥処理を行い脱型 した. 成形体を自然乾燥により $24 \mathrm{~h}$ 乾燥し, 焼成 $\left(\mathrm{ZnO}: 900^{\circ} \mathrm{C}\right.$, $\left.2 \mathrm{~h}, \alpha-\mathrm{Al}_{2} \mathrm{O}_{3}: 1600^{\circ} \mathrm{C}, 2 \mathrm{~h}, 20 \mathrm{~K} / \mathrm{min}\right)$ を行った. 試料焼結後の

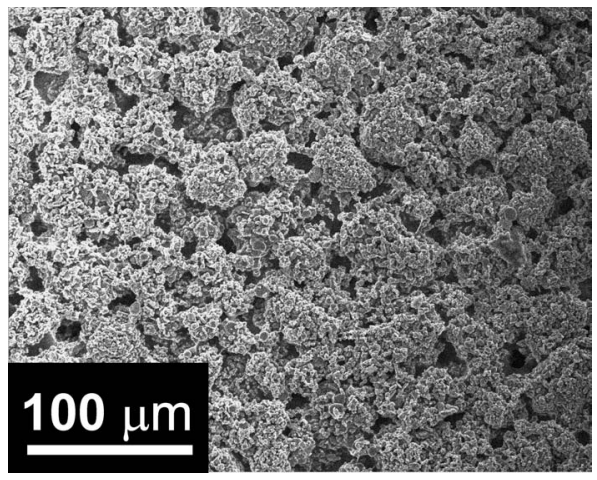

Fig. 2. SEM image of collapse type mold surface.

Table 1. Relative Density and Porosity of the Collapse Type Mold and Gypsum Mold

\begin{tabular}{|c||c|c|}
\hline & Gypsum mold & Collapse type mold \\
\hline \hline relative density / \% & 39.5 & 27.8 \\
\hline open porosity / \% & 51.6 & 72.1 \\
\hline close porosity / \% & 8.9 & 0.1 \\
\hline
\end{tabular}

Table 2. Comparison of the Surface Roughness between Collapse Type Mold and Gypsum Mold

\begin{tabular}{|c|c|c||c|c|c|}
\hline \multicolumn{3}{|c||}{ Gypsum mold } & \multicolumn{3}{c|}{ Collapse type mold } \\
\hline \hline $\mathrm{Ra} / \mu \mathrm{m}$ & $\mathrm{Ry} / \mu \mathrm{m}$ & $\mathrm{Rz} / \mu \mathrm{m}$ & $\mathrm{Ra} / \mu \mathrm{m}$ & $\mathrm{Ry} / \mu \mathrm{m}$ & $\mathrm{Rz} / \mu \mathrm{m}$ \\
\hline 3.60 & 36.58 & 31.82 & 4.46 & 34.21 & 31.64 \\
\hline
\end{tabular}

相対密度はアルキメデス法により測定し，破断面観察は走査型 電子顕微鏡（SEM, JSM-5600N, 日本電子）にて観察した.

\section{1 崩壊式成形型の特性}

\section{4. 結果及び考察}

図 2 に崩壊式成形型表面の SEM 写真を，表 1 に崩壊式成形 型及びセッコウ型の気孔率を示す。図より，崩壊式成形型は約 10 20 $\mu \mathrm{m}$ 程度の気孔があり，そのほとんどが開気孔として存 在している，通常用いられるセッコウ型と比較すると，相対密 度が低く，開気孔率が非常に高いことが分かる. 型の表面粗さ についてセッコウ型と比較したものを表 2 に示す. 表よりセッ コウ型よりも若干表面は粗いものの遜色ない值を示し，また焼 結後の試料表面はセッコウ型を用いて作製した試料と同程度で あった。

\section{2 吸水性を持たせた崩壊式成形型}

今回開発した崩壊式成形型の特徵の一つに，型自体の初期水 分含有量 (5-40 mass \% ) を変えることにより, 吸水性を持たせ 通常の鋳込み型として用いることも，全く吸水性を持たない型 として用いることもできる. 図 3 に, 含有水分量を減らし $(<10$ mass $\%$ ), 吸水性を持たせた開発型の単位面積当たりの吸水量 を示す。セッコウ型と比べると吸水量は少ないが吸水性を示し ていることが分かる. 吸水性が劣る原因は気孔が 10〜20ミク口 ンとセッコウ型に比べ大きいため, 強い毛細管力が望めなかっ たことと, 型材に球状粗大アルミナを用いているため, 濡れ性 の悪さが問題となっていると考えられる. 図 4 に鋳込み時間と 着肉厚さの関係を示す。水分が型に吸収されるのは拡散現象が あるからであり, 型表面に着肉する層の厚さ $L$ と鋳込久時間 $t$ 


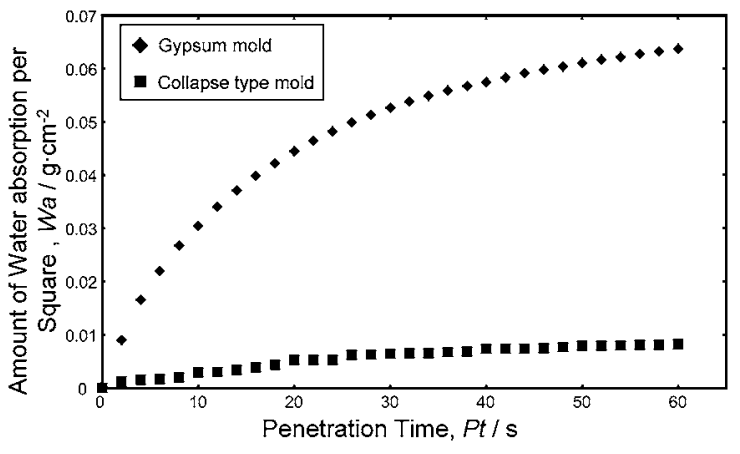

Fig. 3. Relationship between amount of water absorption per square and penetration time.

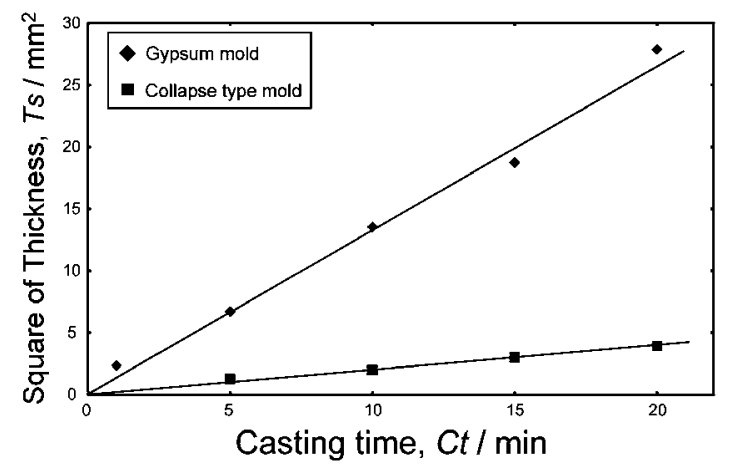

Fig. 4. Relationship between square of the thickness of green body and casting time.

との間には, Darcy の法則 ${ }^{4), 5)} よ り$ 次式のように表される6).

$$
L^{2}=\alpha t
$$

ここで $\alpha$ は着肉速度定数で, 型の吸水能力は時間がたっても 変わらないものと仮定している. 図よりセッコウ型及び開発型 に抢いて，鋳込反時間と着肉厚さの二乗が比例関係にある。 たセッコウ型に比べ開発型の傾きは小さいことから, 着肉速度 が遅いといえる．このことから，開発型はセッコウ型に比べ， 着肉速度は遅いものの, 鋳込みは正常に行われていると考えら れる.

この開発型を用いコンパクトプロセスにより作製した ZnO 試料と，セッコウ型を用い通常工程により作製した $\mathrm{ZnO}$ 試料 の SEM 写真を図 5 に， ZnO 及びアルミナ焼結体の相対密度を 表 3 に示す. 図より, コンパクトプロセスにより作製した ZnO 試料は若干の気孔等が存在するものの, 場所による構造の不均 一もなく, 通常工程のものよりもむしろ高密度な焼結体を得る ことができた.

これは著者らがこれまで報告している77,8), 鋳込反成形体の 乾燥工程にマイクロ波加熱を用いることで，乾燥体の欠陥を抑 えることができ，また均質な焼結体の作製が可能であるとい う，マイクロ波加熱の優位性によるものと， $2.45 \mathrm{GHz}$ 周波数 域に扔ける $\mathrm{ZnO}$ の誘電損率は他のセラミックスに比べ高いた め, 結果マイクロ波を吸収しやすく9),10)，マイクロ波加熱によ る焼成が良好に行われたと考えられる。

一方，コンパクトプロセスによるアルミナ焼結体は，通常工 程 $\left(1600^{\circ} \mathrm{C}, 2 \mathrm{~h}\right.$ 焼成）よりも焼成時間が短く焼成温度も低い $\left(1350^{\circ} \mathrm{C}, 30 \mathrm{~min}\right.$ 焼成）にもかかわらず, 通常工程と遜色ない焼

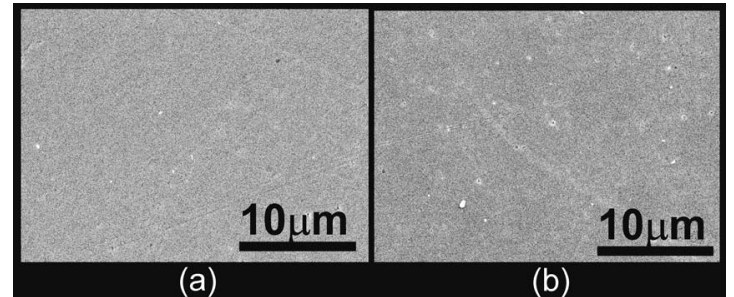

Fig. 5. SEM image of polished fracture surface after sintering. (a) Compact process, and (b) conventional process.

Table 3. Relative Density of the $\mathrm{ZnO}$ and $\alpha-\mathrm{Al}_{2} \mathrm{O}_{3}$ Sintered Bodies Prepared by Conventional Process and Compact Process

\begin{tabular}{|c||c|c|}
\hline \multirow{2}{*}{ Powder } & \multicolumn{3}{|c|}{ Relative Density, $R d / \%$} \\
\cline { 2 - 3 } & This Study & Conv. \\
\hline \hline $\mathrm{ZnO}$ & 97.3 & 94.4 \\
\hline$\alpha-\mathrm{Al}_{2} \mathrm{O}_{3}$ & 97.8 & 98.7 \\
\hline
\end{tabular}

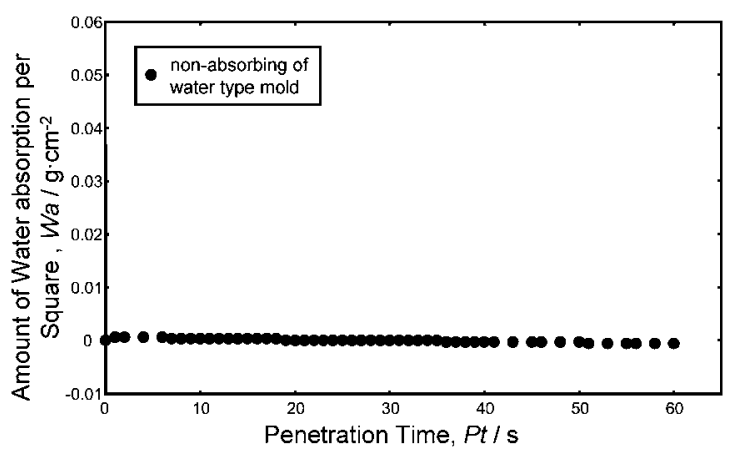

Fig. 6. Relationship between amount of water absorption per square and penetration time.

結体密度を示した、マイクロ波加熱によりセラミックスを焼結 すると, 通常の電気炉での焼成に比べて, 短時間かつ低温で処 理することができ, 結晶粒が微細で緻密な焼結体を得ることが できる ${ }^{11)}$ ，その要因についてはさまざな議論があるが12) 16), 今回の結果も，これまで報告されているようなマイクロ波加熱 効果により，低温かつ短時間で焼結が行われたと考えられる.

\section{3 非吸水性の崩壊式成形型}

図 6 に型の含有水分を飽和量（>40 mass\%) まで増やし， 非吸水性にした開発型の単位面積当たりの吸水量を示す。図よ り型に全く吸水性がないことが分かる，この型を用いると，マ イクロ波加熱ならではの乾燥挙動を利用した新しい成形を行う ことができる.

図 7 に，石英ビーカーに $\mathrm{ZnO}$ スラリーを流入し，(A) 電気 炉及び (B)マイクロ波加熱炉内にて乾燥した写真を示す。マイ クロ波加熱と通常加熱と大きく異なる点は加熱方式の違いであ る. 通常加熱では外部熱源から輻射, 熱伝導, 対流によって熱 が伝えられる外部加熱であるのに対し，マイクロ波加熱では対 象物質の誘電損失により内部から発熱する (内部加熱)。更に 物質固有の誘電損失を利用しているため, 誘電損失の大きい物 質を（相対的に）選択加熱, 局所加熱することができる. スラ リーを構成している物質は, 粒子（この場合 $\mathrm{ZnO}$ ), 溶媒（こ の場合水及び分散剂 PAA）である. そのためスラリーにマイ クロ波を照射する際，マイクロ波は構成物質中，誘電損失の大 


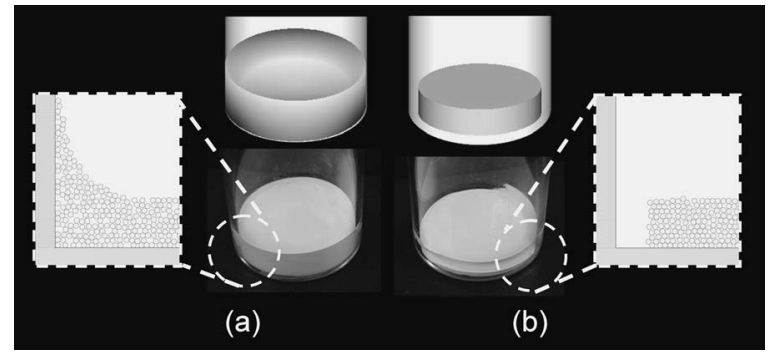

Fig. 7. Appearance photographs of the different drying behaviors in quartz glass beaker. (a) Conventional drying, and (b) microwave drying.

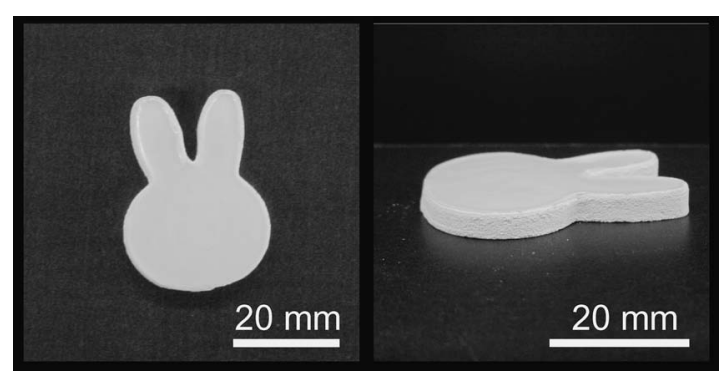

Fig. 8. Photographs of the sintered bodies prepared by compact process using non-absorbing water type mold.

きい物質（この場合水及び PAA）に選択的に吸収され発熱す る. スラリーを成形型に流し乾燥を行うと, 通常加熱の場合外 部（成形型）から熱が伝わる，そのためスラリーの乾燥は成形 型壁面から進み, 成形体上面は図 7(A)のようにメニスカス形 状を形成する，一方マイクロ波加熱の場合溶媒自体が発熱し， 水分は効率的に成形体外部に拡散, 乾燥收縮が行われるため, 成形体は図 7(B)のように全体的に均一に収縮する。このよう な乾燥挙動は, 非吸水性にした開発型内に抢いても同様に観測 される.この手法にて作製した試料は, 均質な乾燥収縮により 高い密度を得ることができる. 更に, 図 8 の示すように, 反り もなく上面も平らに作製することができ，成形型の形状を変え ることでさまざまな形状の成形体を作製することができる。 た得られる成形体は, 著者のこれまでのマイクロ波乾燥に関す る報告7)のように反りや割れ, 密度ムラといった久陷が少ない 特長を持ち, これまでにないユニークな成形, 焼成手法と言え る.

\section{4 焼成後の型材}

図 9 に焼成後の型材粉末の粒度分布を示す。図より $1400^{\circ} \mathrm{C}$ での仮焼では粒成長は見られず原料粉末と同様の粒度分布を示

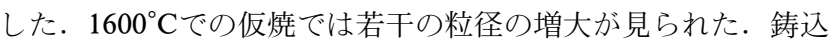
み型に用いたアルミナ粒子は，セラミックス製品を製造するう えで用いられる原料粉末よりも粒径の粗大な, 焼結性の低い粒 子を選択しているため, 鋳込み型自体の焼結性がそしく, 焼成 温度のような高温状態でも焼結が起こりにくい。 また型自体の 強度が弱いため, 内部の試料が焼結時に収縮しても試料の拘束 等の悪影響を及ぼさない。その結果，試料焼成後の鋳込み型 は，簡単に崩壊し，型原料の粉末と性質がほとんど変わらな い. 更に本プロセスの加熱工程にはマイクロ波加熱を用いてい るため, 通常の電気炉での焼成に比べて低温かつ短時間での焼 結が可能であることから，焼成時に抢ける型材粉末への影響は

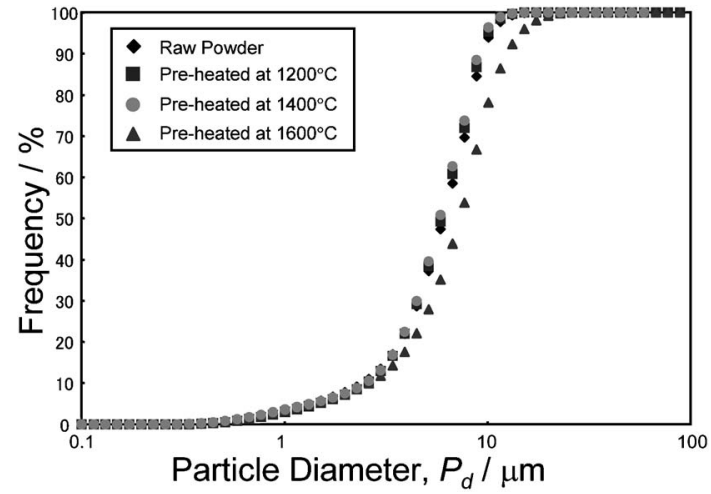

Fig. 9. Particle size distribution of alumina powder for mold after calcinations.

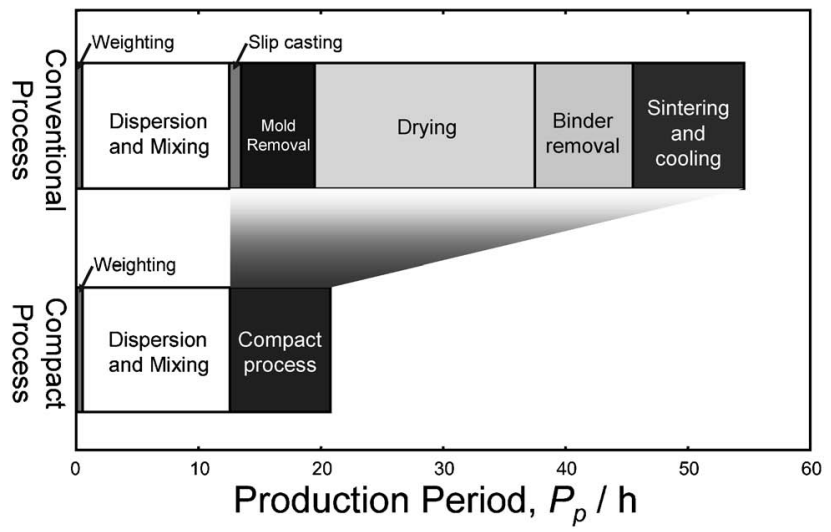

Fig. 10. Comparison of the production period for alumina sintering between compact process and conventional process.

小さいと考えられる．そのため型材粉末は再利用しても型とし ての特性になんら影響を及ぼすことはない。実際型材を再利用 し同様のプロセスで試料を作製しても，鋳込久特性，焼結後の 試料特性等に変化はなかった.

\section{5 本開発手法による工程時間短縮効果}

図10に鋳込み成形による通常工程及び本コンパクトプロセス における，アルミナ焼成に必要な工程時間を示す。通常工程で は焼成過程までの工程（鋳込み，脱型，乾燥）にかかる時間が 非常に長い。特に乾燥工程は反りや割れ, 密度ムラといった欠 陥が発生しやすく, 例え乾燥後, これらの欠陷が見られなくて も，焼成時に欠陥が成長して不良品となる場合もある。そのた め通常, 乾燥雾囲気の湿度を調節しながら，なるべく低い温度 でゆっくりと乾燥させる ${ }^{8)}$. 乾燥工程時に発生する欠陥の主な 発生原因は, 成形体内の乾燥収縮差によるものである. 成形体 内には収縮差により応力が発生するが, 乾燥初期段階に抢いて は, 十分な水分があるために可塑変形によって応力は緩和され る. しかし乾燥が進み可塑変形できない水分域に達すると, 応 力が緩和されず成形体に欠陥が発生する。一方マイクロ波加熱 による乾燥は, 成形体内部の水が選択的に加熱され, 成形体内 の場所による温度ムラが小さい，また水自身が発熱することか ら, 粒子間の気孔水の温度も通常加熱々比べ, 高く維持するこ とが可能である. その結果, 気孔水の表面張力を減少させ, 毛 細管力による成形体表面への水の拡散を容易にし, 効率よく乾 燥が進行すると考えられる ${ }^{8), 17)}$ 。このような理由からマイクロ 
波加熱では, 通常行われる乾燥時の䨌囲気湿度の調節や乾燥調 整剂等の使用をせずとも，乾燥後の成形体の欠陥を抑制し，均 質な成形体構造を作製することが可能であり，大幅な工程時間 短縮を実現することができる.

またコンパクトプロセスでは成形, 乾燥, 焼成を同一工程で 行うため脱型工程を省くことができ, 結合剂を使う必要がな い，そのため脱脂工程が不要となる．加熱により結合剂を除去 する脱脂工程は, 試料の種類, 形状, 大きさによっては数十〜 数百時間に及ぶこともある. また有機結合剤の分解脱ガスの発 生に伴い, 成形体内部にボイドやデラミネーションを生ずる.

そのため通常成形体の脱脂工程では通常低速の昇温速度が選択 される.しかし, 結合剂が完全に除去される温度まで低速で加 熱するには, 工程時間の長さもさることながら, 費やす投入工 ネルギーも無視できない量である。そのため, 結合材を使わ ず，脱脂工程を省略できる本コンパクトプロセスは低環境負荷 の観点からも優れた製造方法といえる. 本コンパクトプロセス によって, 成形から焼成までの工程時間を, 通常工程に比べ約 $1 / 5$ 短縮することができ, 全体の工程時間を半分以下に短縮す ることに成功した．またマイクロ波加熱を用いることで，焼成 温度の低温化, 焼成時間の短縮化が可能であることから，投入 エネルギー削減効果も絶大といえる，今回はスラリー作製には 通常用いられるボールミル法により調整したが, 著者らの研究 グループで報告している湿式ジェットミル ${ }^{18) ~ 20) に よ り ス ラ ~}$ リーを作製すれば，大幅な工程時間短縮だけではなく，低粘 度・低再凝集スラリーを得ることもでき, 短時間で高品質なセ ラミックス製品の開発が可能となる. また本コンパクトプロセ スに打汻業手順は，スラリー鋳込久後マイクロ波加熱炬に 投入するのみであることから，セラミックス製造プロセス自動 化への応用も期待できる.

\section{5. まとめ}

著者らは，工程時間短縮及び投入エネルギー削減の観点か ら，マイクロ波加熱用いた，セラミックス製造に打ける成形 乾燥・焼成の各工程を統合化するコンパクトプロセスを開発し た ${ }^{2}$. 本プロセスのために新しく開発した型は, 鋳込み, 乾燥 時には成形型として, 焼成時には断熱材及びマイクロ波吸収の サセプターとして作用し，また焼成後は崩壊するため製品の取 出しが容易となる等, 複数の機能を持ち合わせている. 成形, 乾燥, 焼成を同一工程で行うため脱型工程を省くことができ, バインダーを使う必要がない。そのため脱脂工程が不要とな り，工程時間の大幅な短縮化も可能となる. 加熱過程にマイク ロ波加熱を用いたことにより，これまで報告している乾燥，焼 成時に発生するそりや割れ，密度ムラといった欠陥を抑制する ことができ，本コンパクトプロセスにより作製した試料の焼結 体特性は, 通常工程のものと同程度であるなど, 短時間で高品 質な焼結体を得ることに成功した．更にコンパクトプロセスに
よって, 成形から焼成までの工程時間を, 通常工程に比べ約 $1 / 5$ 短縮することができ, 全体の工程時間を半分以下に短縮す ることに成功した，またマイクロ波加熱を用いることで，焼成 温度, 時間を短縮することも可能であることから, 投入エネル ギー削減効果も大きい，また本コンパクトプロセスにおける作 業手順は，スラリ一鋳込み後マイクロ波加熱炉に投入するのみ であることから，セラミックス製造プロセス自動化への応用も 期待できる.

\section{References}

1) http://www.enecho.meti.go.jp/topics/hakusho/ 2006EnergyHTML/index.html.

2) Yasuoka, M., Shirai, T., Hotta, Y. and Watari, K., Patent, J. P., No. 2006-46108 (2006).

3) Shiraki, Y., "Ceramic-Seizo-Process I," Gihodo Shuppan (1978) pp. 175-286 [in Japanese].

4) Niet, M. I., Moreno, R., Salomoni, A. and Stamenkovic, I., Am. Ceram. Soc. Bull., Vol. 77, pp. 62-66 (1998).

5) Hotta, Y., Banno, T. and Oda, K., J. Mater. Sci., Vol. 37, pp. 417-423 (2002).

6) Adcock, D. S. and McDowall, I. C., J. Am. Ceram. Soc., Vol. 40, pp. 355-362 (1957).

7) Shirai, T., Yasuoka, M., Hotta, Y. and Watari, K., J. Ceram. Soc. Japan, Vol. 114, pp. 217-219 (2006).

8) Shirai, T., Yasuoka, M., Hotta, Y., Kinemuchi, Y. and Watari, K., Adv. In Tech. of Mat. Proc. J. (ATM), Special Issue NHM2006 (2006) in press.

9) Fukushima, H., Watanabe, G., Mori, H. and Matsui, M., Toyota-Chuo-Kenkyuzyo R\&D Review, Vol. 30, pp. 25-34 (1995).

10) Ikuma, Y. and Takahashi, K., J. Ceram. Soc. Japan, Vol. 100, pp. 1327-1331 (1992).

11) Saji, T., "Seramikkusuno-Kousokusyouketugizyutsu," TIC Corp. (1998) pp. 17-33.

12) Janney, M. A. and Kimrey, H. D., MRS Symp. Proc., Vol. 189, pp. 215-227 (1991).

13) Zhang, J., Cao, L. and Xia, F., MRS Symp. Proc., Vol. 269, pp. 329-334 (1992).

14) Kimrey, H. D., Kiggans, J. O., Janney, M. A. and Beatty, R. L., MRS Symp. Proc., Vol. 189, pp. 243-255 (1991).

15) Meek, T. T., J. Mater. Sci. Lett., Vol. 6, pp. 638-640 (1987).

16) Swain, B. and Snyder, W. B., Advanced Metals \& Processes, Vol. 9, pp. 76-82 (1988).

17) Shirai, T., Yasuoka, M., Hotta, Y., Kinemuchi, Y. and Watari, K., J. Ceram. Soc. Japan, submitted.

18) Omura, N., Hotta, Y. Sato, K., Kinemuchi, Y., Kume, S. and Watari, K., J. Ceram. Soc. Japan, Vol. 113, pp. 491-494 (2005).

19) Omura, N., Hotta, Y., Sato, K., Kinemuchi, Y., Kume, S. and Watari, K., J. Ceram. Soc. Japan, Vol. 113, pp. 495-497 (2005).

20) Omura, N., Hotta, Y., Sato, K., Kinemuchi, Y., Kume, S. and Watari, K., J. Am. Ceram. Soc., Vol. 89, pp. 2738-2743 (2006). 